\title{
WIELOPRZĘSŁOWE WIADUKTY ZINTEGROWANE Z PRZĘSŁAMI SKRZYNKOWYMI - DOŚWIADCZENIE PROJEKTANTA
}

\author{
Andrzej Helowicz ${ }^{\bowtie}$ \\ Wydział Budownictwa Lądowego i Wodnego, Politechnika Wrocławska, Wrocław
}

\begin{abstract}
STRESZCZENIE
W artykule przedstawiono charakterystyczne cechy mostów zintegrowanych na przykładzie realizacji dwóch zintegrowanych, wieloprzęsłowych wiaduktów drogowych o konstrukcji żelbetowej. Wiadukty te wykonano w ciągu drogi krajowej N18, na wyjeździe z miasta Limerick w kierunku miasta Galway w Irlandii. We wstępie opisano zasady kształtowania i modelowania wiaduktów zintegrowanych. Następnie przedstawiono konstrukcje zintegrowanych wiaduktów, których autor był projektantem sprawdzającym. Zwrócono uwagę na zalety i wady oraz koszty wykonania tych obiektów. Rozpatrywano cały proces powstawania obiektu od projektowania i budowy do zachowania się zintegrowanych wiaduktów w trakcie ich użytkowania. W podsumowaniu zawarto wiedzę i doświadczenia autora w trakcie projektowania oraz sformułowano zalecenia projektowe takich obiektów w Polsce.
\end{abstract}

Słowa kluczowe: wieloprzęsłowy wiadukt zintegrowany, przęsło skrzynkowe, projektowanie i budowa

\section{WSTĘP}

Projektując wiadukt drogowy, należy brać pod uwagę koszty budowy konstrukcji oraz wydatki związane z jego eksploatacją. Obiekt powinien być ekonomiczny, nowoczesny, trwały i powinien spełniać wszystkie wymogi norm oraz specyfikacji technicznej zamawiającego. Przy wyborze technologii konieczne jest uwzględnienie tempa prac budowlanych, co zmusza budowniczych do szukania nowoczesnych technik wykonania. Takie warunki spełniają rozwiązania konstrukcyjne w postaci wiaduktów zintegrowanych.

Wiadukt zintegrowany zdefiniować można jako obiekt mostowy, którego przęsła są monolitycznie połączone z podporami pośrednimi i ścianami przyczółków, a jego konstrukcja wskutek oddziaływań termicznych oraz obciążeń stałych i zmiennych (pojazdów i pieszych) współpracuje z otaczającym ją gruntem. Dzięki temu w omawiannych obiektach nie występują takie elementy, jak: łożyska mostowe, urządzenia dylatacyjne i płyty przejściowe. Zastosowanie tych elementów może być wskazane w przypadkach, gdy długość obiektu przekracza $60 \mathrm{~m}$, a kąt skosu obiektu nie jest mniejszy niż 60 (BA42/96, 2003), oraz w przypadku jego budowy na gruntach słabonośnych, jak to ma miejsce w opisywanych dwóch wiaduktach drogowych. W tych mostach krótszy jest też czas budowy w porównaniu z tradycyjnie budowanymi wiaduktami o podobnych gabarytach, w których zastosowano i wykonano powyższe elementy. Brak wymienionych elementów i krótszy czas budowy prowadzi do redukcji kosztów budowy obiektów mostowych.

Łożyska i dylatacje podlegają w trakcie eksploatacji mostu zużyciu, a więc należy je wymieniać. Koszty wymiany mogą przekroczyć ich pierwotne wbudowanie. Dodatkowo, w trakcie wymiany łożysk i dylatacji

凶andrzej.helowicz@pwr.edu.pl 
konieczne jest kilkudniowe zamknięcie ruchu na obiekcie oraz na drodze dojazdowej do obiektu. Zamknięcie drogi powoduje zwiększenie natężenia ruchu na drogach przejmujących ruch z zamkniętej drogi i tym samym zwiększenie ryzyka powstawania wypadków drogowych. W wyniku tego wiadukty zintegrowane są także tańsze w utrzymaniu, bezpieczniejsze i mniej uciążliwe w eksploatacji w porównaniu z klasycznymi mostami i wiaduktami.

Ponadto brak dylatacji mostowych powoduje, że woda opadowa na wiadukcie może płynąć bezpośrednio poza obiekt, a nie między przęsło i przyczółek mostowy, co ma często miejsce w przypadku uszkodzonej dylatacji mostowej. Jest to szczególnie groźne w okresie zimy, gdy woda opadowa zmieszana z solą do posypywania dróg zmienia się w lód, który ma około $10 \%$ większą objętość od wody, z której powstał i w konsekwencji prowadzi do rozsadzania podpór mostowych. Słona woda, wnikając w głąb konstrukcji, powoduje również szybką degradację stali i betonu, z których wykonane są elementy konstrukcyjne wiaduktu. Spływająca po konstrukcji brudna woda opadowa dodatkowo szpeci elewację obiektu. W rezultacie wiadukty zintegrowane są również trwalsze niż wykonane tradycyjnie.

Mosty i wiadukty zintegrowane stosowane są w USA od lat 30. XX wieku, kiedy zaczęto intensywną budowę autostrad. W Europie, m.in. w Wielkiej Brytanii zaczęto stosować tę metodę od 1959 roku, gdy tak jak w USA rozpoczęto budowę autostrad. Podobnie jest w innych wysoko rozwiniętych państwach Europy. W Polsce już na początku lat 30 . XX wieku pojawiły się pierwsze publikacje propagujące mosty bez łożysk mostowych, o schematach pozornie ramowych (Wasiutyński, 1985). Zasadą pracy tych mostów i wiaduktów była integralność przęsła i podpór. W pracach z tego okresu nasz znakomity uczony profesor Wasiutyński opisał zalety zarówno konstrukcyjne, jak i efektywność ekonomiczną tych obiektów.

Pierwsze obiekty tego typu powstały w Polsce w drugiej połowie lat 30. ubiegłego wieku. Obecnie w Polsce dominuje konserwatywne i mało ekonomiczne podejście do projektowania mostów i wiaduktów. Polega ono na założeniu, że przęsło i przyczółek to dwa elementy konstrukcyjne połączone kosztownym łożyskiem mostowym, które przekazuje jedynie siłę pionową i część poziomej, bez momentu podporowego, który jest mały lub go nie ma wcale. W ten prosty i szybki w obliczeniach sposób osobno projektuje się przęsło mostowe, osobno podpory. Jest to widoczne w naszym kraju, gdzie na budowanych odcinkach dróg duża liczba mostów i wiaduktów jest wyposażona w kosztowne elementy: łożyska mostowe, dylatacje czy też płyty przejściowe. Dawniej, gdy projektant $\mathrm{w}$ najlepszym przypadku dysponował jedynie mechanicznymi urządzeniami wspomagającymi obliczenia, konserwatywne podejście do projektowania było częściowo uzasadnione. Obecnie komputery posiadają dużą moc obliczeniową, więc projektowanie mostów zintegrowanych przy ich wykorzystaniu nie stanowi już problemu. Projektując znane i powszechnie stosowane na świecie mosty i wiadukty zintegrowane, otrzymuje się tańsze w budowie i utrzymaniu oraz trwalsze konstrukcje.

Niniejszy artykuł poświęcony jest projektowaniu i budowie dwóch wieloprzęsłowych wiaduktów zintegrowanych z przęsłami o przekroju skrzynkowym. Co więcej, inne typy obiektów zintegrowanych, takie jak: wiadukty jednoprzęsłowe, dwuprzęsłowe i mosty łukowe, których zastosowanie znacząco zmniejsza koszt i czas ich budowy, opisane są w pracach Helowicza (2015a, 2015b, 2016).

\section{PRZYKŁADY ZINTEGROWANYCH WIADUKTÓW DROGOWYCH}

W artykule przedstawione są dwa wiadukty zintegrowane znajdujące się w hrabstwie Clare w Irlandii w ciągu drogi krajowej N18, łączące miasta Limerick i Galway (rys. 1, 2, 3). Obiekty te były częścią dużego projektu związanego z budową południowej obwodnicy miasta Limerick i tunelu pod rzeką Shannon w Irlandii. Wiadukt północny przeprowadza ruch z miasta Galway do miasta Limerick (rys. 4), natomiast wiadukt południowy w kierunku przeciwnym. Na obydwu wiaduktach, o przekroju skrzynkowym (rys. 5), zaprojektowano dwie jezdnie o szerokości $7 \mathrm{~m}$, z pasem awaryjnym szerokości $2,5 \mathrm{~m}$. Dodatkowo na wiadukcie południowym znajduje się chodnik techniczny szerokości 3,25 m. Pas rozdziału ruchu ma szerokość 3,6 m. 


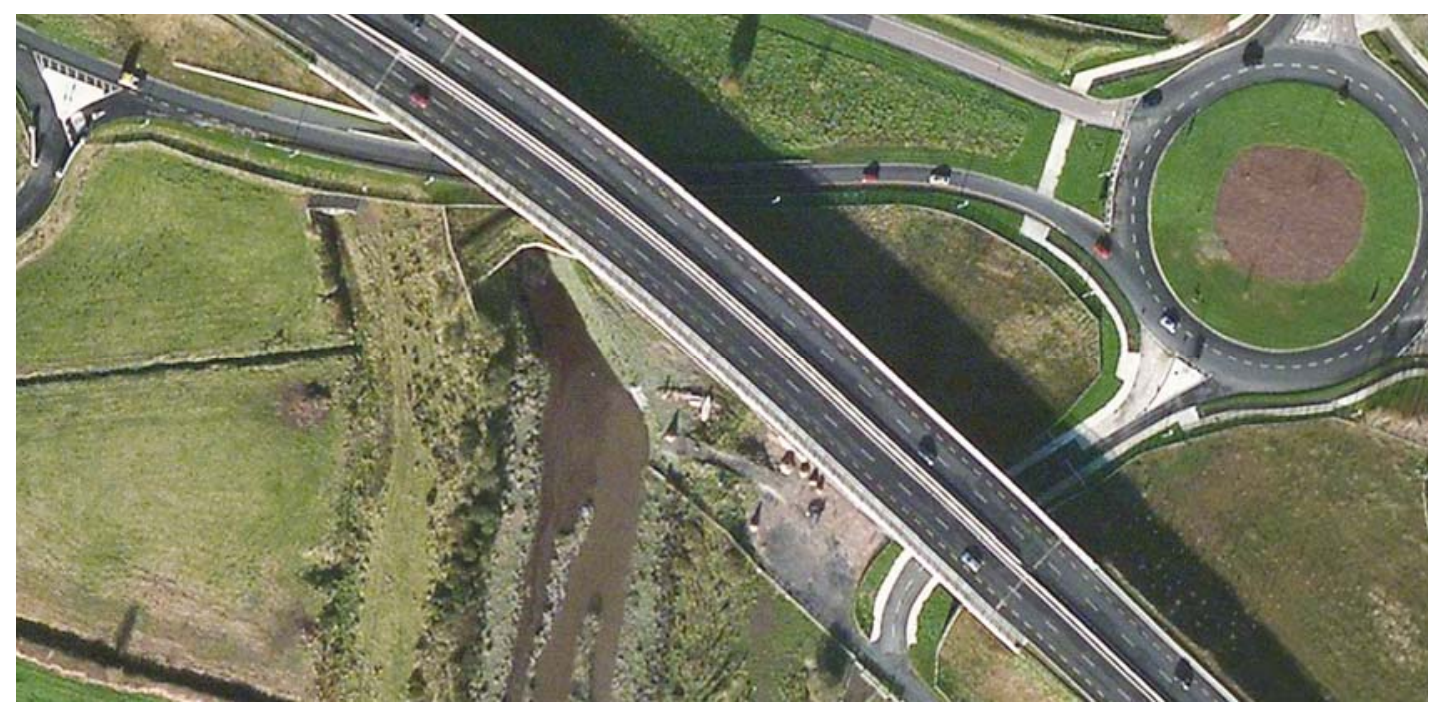

Rys. 1. Widok z góry na wykonane wiadukty (Microsoft Bing Maps)

Fig. 1. The top view on the viaducts - completed structures (Microsoft Bing Maps)

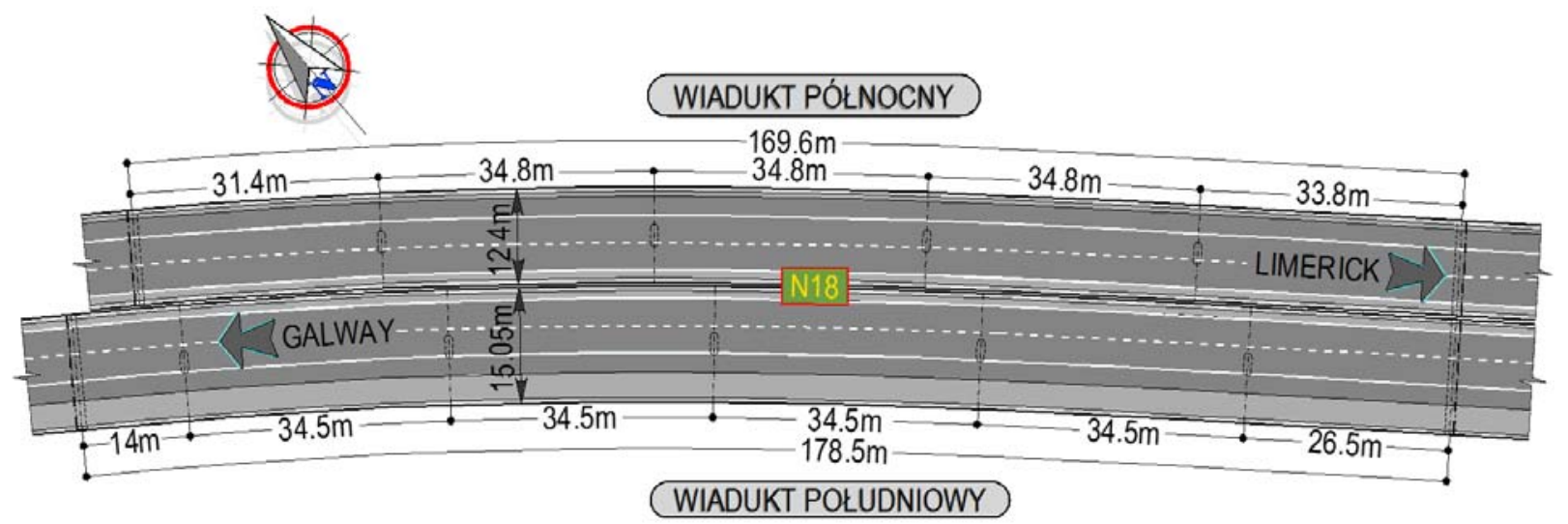

Rys. 2. Widok $\mathrm{z}$ góry na wiadukty $\mathrm{z}$ podziałem na rozpiętości przęseł

Fig. 2. The top view on the viaducts - dimensions of the viaducts spans

Obydwie konstrukcje wyposażono w stalowe bariery ochronne z wbudowaną siatką wysokości 1,25 m i bariery betonowe typu New Jersey. Podstawowe parametry obydwu konstrukcji podano w tabeli 1. Dokumentację projektową, bez jej sprawdzenia, wykonano w biurze konsultingowym Roughan \& O’Donovan z Dublina. Zgodnie kontraktem obydwa wiadukty musiały być sprawdzone w zewnętrznym, niezależnym biurze konsultingowym posiadającym doświadczenie przy projektowaniu tego typu konstrukcji. Do tego celu wybrano biuro konsultingowe Fehily Timoney \& Company Consultants z Cork. Pracując w tym biurze, autor sprawdził zaprojektowane wiadukty.

Do sprawdzenia zaprojektowanych wiaduktów wykorzystano m.in. normy: obciążenia mostów zintegrowanych (BA42/96, 2003), obciążenia mostowe (BD37/01, 2001), wymiarowanie elementów stalowych (BS5400-03, 2000), wymiarowanie elementów żelbetowych (BS5400-04, 1990), wymiarowanie konstrukcji zabezpieczających grunt (BS8002, 1994). 
Tabela 1. Podstawowe parametry obydwu wiaduktów

Table 1. The basic information of both viaducts

\begin{tabular}{lcc}
\hline $\begin{array}{l}\text { Elementy } \\
\text { Elements }\end{array}$ & $\begin{array}{c}\text { Wiadukt północny } \\
\text { Northern viaduct }\end{array}$ & $\begin{array}{c}\text { Wiadukt południowy } \\
\text { Southern viaduct }\end{array}$ \\
\hline $\begin{array}{l}\text { Rozpiętość teoretyczna wiaduktu } \\
\text { Design length of viaduct deck }\end{array}$ & $L_{t}=169,6 \mathrm{~m}$ & $L_{t}=178,5 \mathrm{~m}$ \\
$\begin{array}{l}\text { Długość całkowita wiaduktu } \\
\text { Overall viaduct length }\end{array}$ & $L^{\prime}=170,8 \mathrm{~m}$ & $L=179,7 \mathrm{~m}$ \\
& & $L_{t 1}=14,0 \mathrm{~m}$ \\
& $L_{t 1}=31,4 \mathrm{~m}$ & $L_{t 2}=34,5 \mathrm{~m}$ \\
Rozpiętości teoretyczne poszczególnych przęseł & $L_{t 2}=34,8 \mathrm{~m}$ & $L_{t 3}=34,5 \mathrm{~m}$ \\
Design length of each span, measured between centres of supports & $L_{t 3}=34,8 \mathrm{~m}$ & $L_{t 4}=34,5 \mathrm{~m}$ \\
& $L_{t 4}=34,8 \mathrm{~m}$ & $L_{t 5}=34,5 \mathrm{~m}$ \\
& $L_{t 5}=33,8 \mathrm{~m}$ & $L_{t 6}=26,5 \mathrm{~m}$ \\
Szerokość całkowita przęsła & & $b=15,05 \mathrm{~m}$ \\
Overall deck width & $b=14,4 \mathrm{~m}$ & \\
Maksymalna wysokość konstrukcyjna przęsła & $h_{k}=1,73 \mathrm{~m}$ & $h_{k}=1,97 \mathrm{~m}$
\end{tabular}

Maksymalne podniesienie wykonawcze przęseł

Maximum deck precamber

$0,06 \mathrm{~m}$

Konstrukcje przęseł $\mathrm{z}$ betonu klasy

Deck concrete class

$\mathrm{C} 60 / 75$

Konstrukcje przyczółków i podpór pośrednich z betonu klasy

Abutment and intermediate supports concrete class

$\mathrm{C} 50 / 60$

Kąt skrzyżowania obiektu z przeszkodą

Viaduct skews

$\alpha=90^{\circ}$

Liczba przęseł

Number of spans

5

6

Grubość górnej i dolnej płyty przęsła

Depth of top and bottom deck slab

0,25 i $0,18 \mathrm{~m}$

Minimalna i maksymalna szerokość dźwigara

Minimum and maximum width of girder

Kąt pochylenia dźwigara

Inclination angle of girder

$b=0,30$ i $0,60 \mathrm{~m}$

$b=0,30$ i $0,50 \mathrm{~m}$

Wysokość dźwigara

Height of girder

Minimalne i maksymalne pole przekroju poprzecznego przęsła

Minimum and maximum cross-section area of deck

Grubość i szerokość ściany przyczółka

Depth and width of abutment wall

$h_{d}=1,5 \mathrm{~m}$

$$
\begin{array}{ll}
A_{p}^{\min }=5,2 \mathrm{~m}^{2} & A_{p}^{\min }=6,9 \mathrm{~m}^{2} \\
A_{p}^{\max }=5,8 \mathrm{~m}^{2} & A_{p}^{\max }=7,5 \mathrm{~m}^{2} \\
1,2 \times 12,2 \mathrm{~m} & 1,2 \times 14,85 \mathrm{~m} \\
2,25 \div 2,55 \mathrm{~m} & 2,5 \div 2,7 \mathrm{~m}
\end{array}
$$

Minimalna i maksymalna wysokość ściany przyczółka

Minimum and maximum height of abutment wall

Liczba podpór pośrednich

Number of intermediate supports

Grubość i szerokość podpory pośredniej

Depth and width of intermediate supports

$1,0 \times 2,8 \mathrm{~m}$ 
Tabela $1-$ cd.

Table 1 - cont.

Minimalna i maksymalna i wysokość podpory pośredniej

Minimum and maximum height of intermediate supports

Wymiary oczepu podpory pośredniej

Overall dimension of intermediate support pilescap

$b, h, l$

Liczba pali pod pojedynczą podporą pośrednią i ścianą przyczółka Number of piles under each intermediate support and abutment wall

Maksymalna głębokość wbicia pali w grunt rodzimy

Maximum driven depth of pile

Wysokość nasypu

Abutment height

Obciążenie ruchome, typ

Type of bridge live loads

Proporcja długości do wysokości przęsła

Deck length to height ratio

\author{
$7,55 \div 9,0 \mathrm{~m}$ \\ $7,05 \div 8,35 \mathrm{~m}$ \\ $3,0 \times 1,2 \times 10,5 \mathrm{~m}$ \\ $3,0 \times 1,2 \times 13,5 \mathrm{~m}$
}

8 i 6

10 i 6

$\sim 25 \mathrm{~m}$

$\sim 9 \mathrm{~m}$

HA i HB37,5

23.2

Dodatkowo przy projektowania wykorzystano irlandzkie specyfikacje techniczne do robót drogowych (NRA Manual, 2000) i najnowsze zalecenia podane przez inwestora (National Road Authority).

Obydwie konstrukcje położone są blisko siebie i przekraczają te same przeszkody, jakimi są droga R445 i ujście rzeki Cratloe. Obiekty te położone są na terenach zalewowych największej w Irlandii rzeki Shannon, której szerokość w pobliżu wiaduktu wynosi około $360 \mathrm{~m}$. Odległość wiaduktów do brzegu rzeki Shannon wynosi około $750 \mathrm{~m}$ (rys. 3).

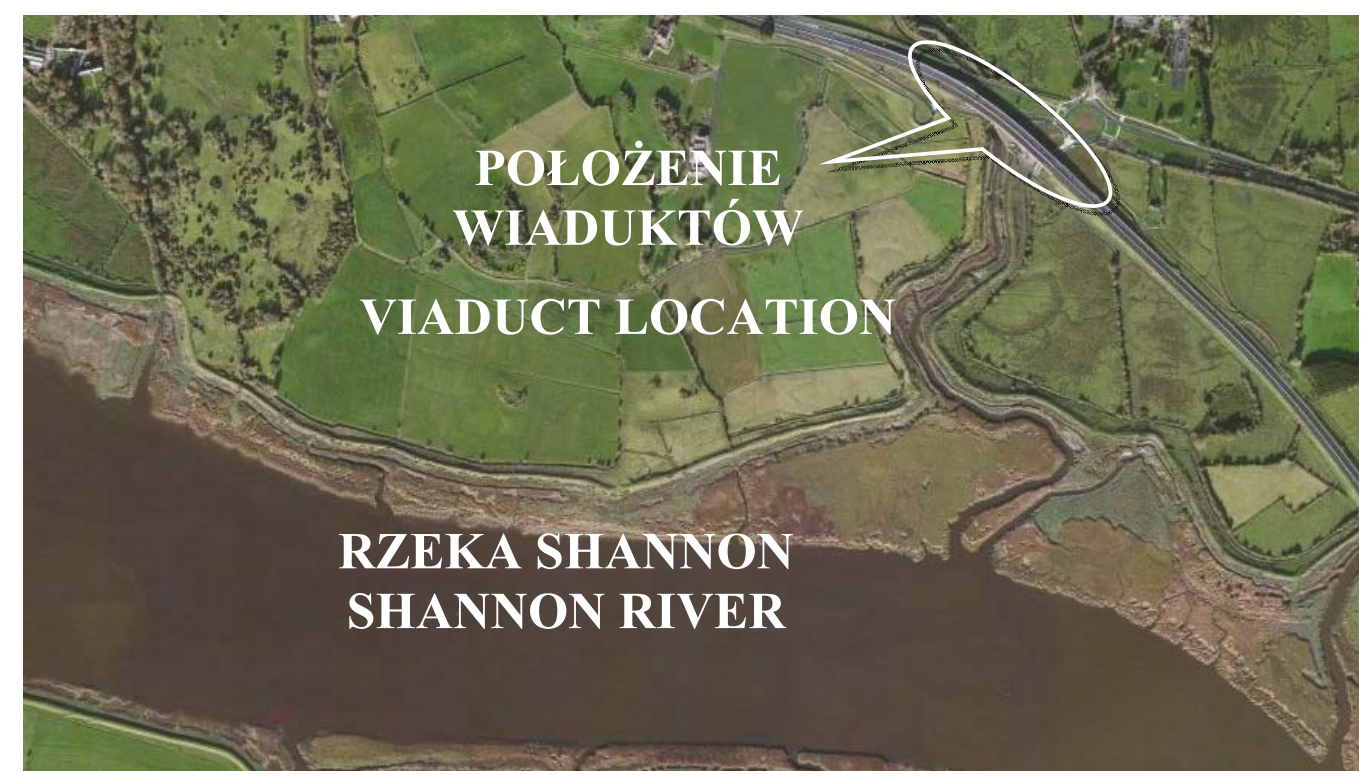

Rys. 3. Widok z góry na wiadukt i rzekę Shannon (Microsoft Bing Maps)

Fig. 3. The top view on the viaducts and the river Shannon (Microsoft Bing Maps) 


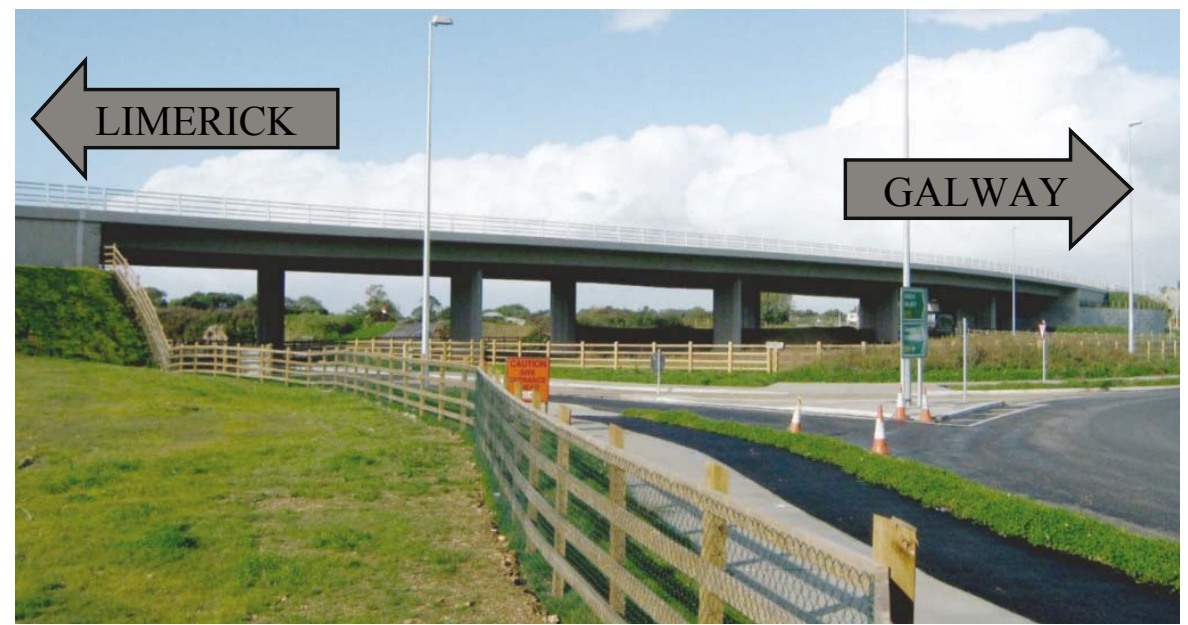

Rys. 4. Widok z boku na wiadukt północny (Roughan \& O’Donovan Consultancy)

Fig. 4. Side view on the northern viaduct (Roughan \& O'Donovan Consultancy)

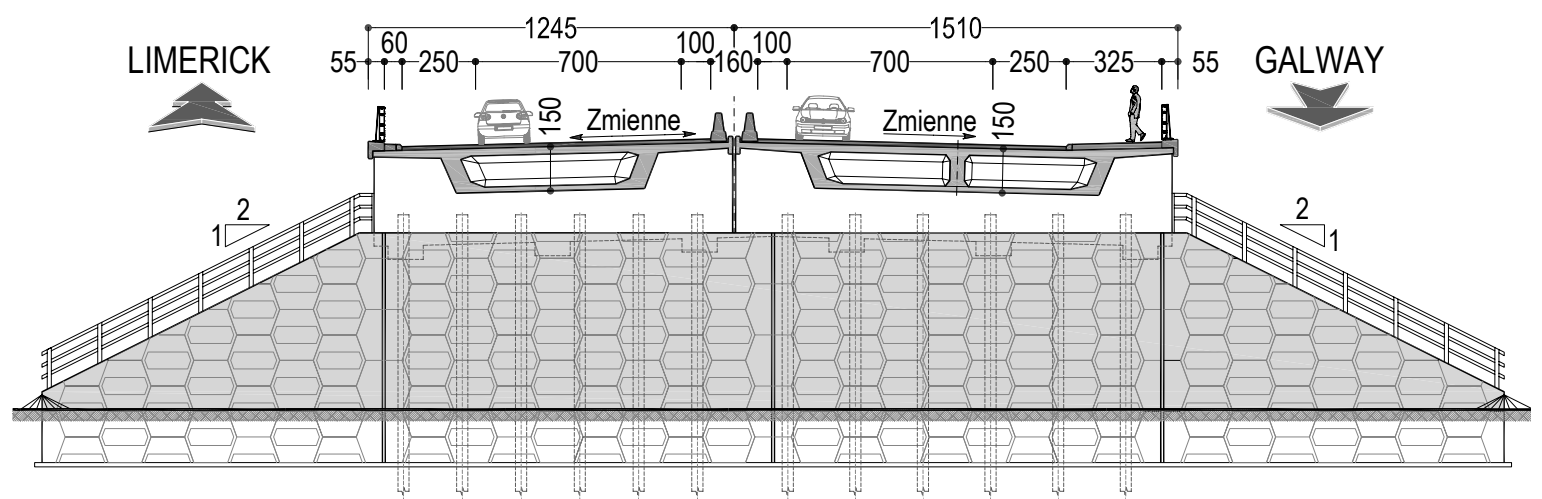

Rys. 5. Skrzynkowy przekrój poprzeczny wiaduktów

Fig. 5. A cross-section of the viaducts with box girders

Przy budowie obydwu wiaduktów można wyróżnić następujące etapy prac:

- wykonanie wykopów,

- wbicie pali stalowych,

- wykonanie oczepów pali,

- wykonanie podpór pośrednich, filarów,

- wykonanie ścian przyczółków,

- wykonanie dwudziestometrowych fragmentów przęsła nad podporami pośrednimi; fragmenty te to przęsła wspornikowe długości $10 \mathrm{~m}$, rozchodzące się od osi filara wzdłuż osi drogi,

- utwierdzenie jednego z końców przęsła wspornikowego za pomocą dwóch odciągów stalowych do bloków metalowych ułożonych na gruncie, dzięki czemu można było wykonać fragment przęsła łączącego przęsło wspornikowe po drugiej stronie filaru z przęsłem wspornikowym leżącym na sąsiednim filarze,

- wykonanie fragmentu przęsła łączącego przęsło wspornikowe z przęsłem wspornikowym na sąsiednim filarze,

- wykonanie fragmentu przęsła łączącego przęsło wspornikowe z przyczółkiem mostowym, 
- wykonanie ścian oporowych z gruntu zbrojonego po obu stronach wiaduktu,

- wykonanie płyty dojazdowej do wiaduktu od strony południowo-wschodniej,

- wykonanie drenażu za ścianami przyczółków,

- zasypanie przyczółków zasypką klasy 6C,

- wykonanie płyt przejściowych na obydwu końcach wiaduktów,

- wykonanie chodników,

- wykonanie izolacji mostowych,

- montaż barier ochronnych,

- położenie nawierzchni drogowej,

- montaż ogrodzenia drewnianego z siatką na nasypie wzdłuż ściany oporowej z gruntu zbrojonego.

\section{KONSTRUKCJA PRZĘSŁA}

Przęsło wiaduktu północnego zaprojektowano jako konstrukcję ciągłą pięcioprzęsłową, natomiast przęsło wiaduktu południowego - jako układ sześcioprzęsłowy. W obydwu wiaduktach przęsła są monolitycznie połączone z podporami pośrednimi i ścianami przyczółków. Ze względu na różną szerokość przęseł w obydwu wiaduktach węższe przęsło wiaduktu północnego ma przekrój skrzynkowy jednokomorowy, natomiast szersze przęsło wiaduktu południowego ma przekrój skrzynkowy dwukomorowy. Konstrukcje tych przęseł wykonane są ze zbrojonego betonu klasy C60/75 (rys. 6 i 7).
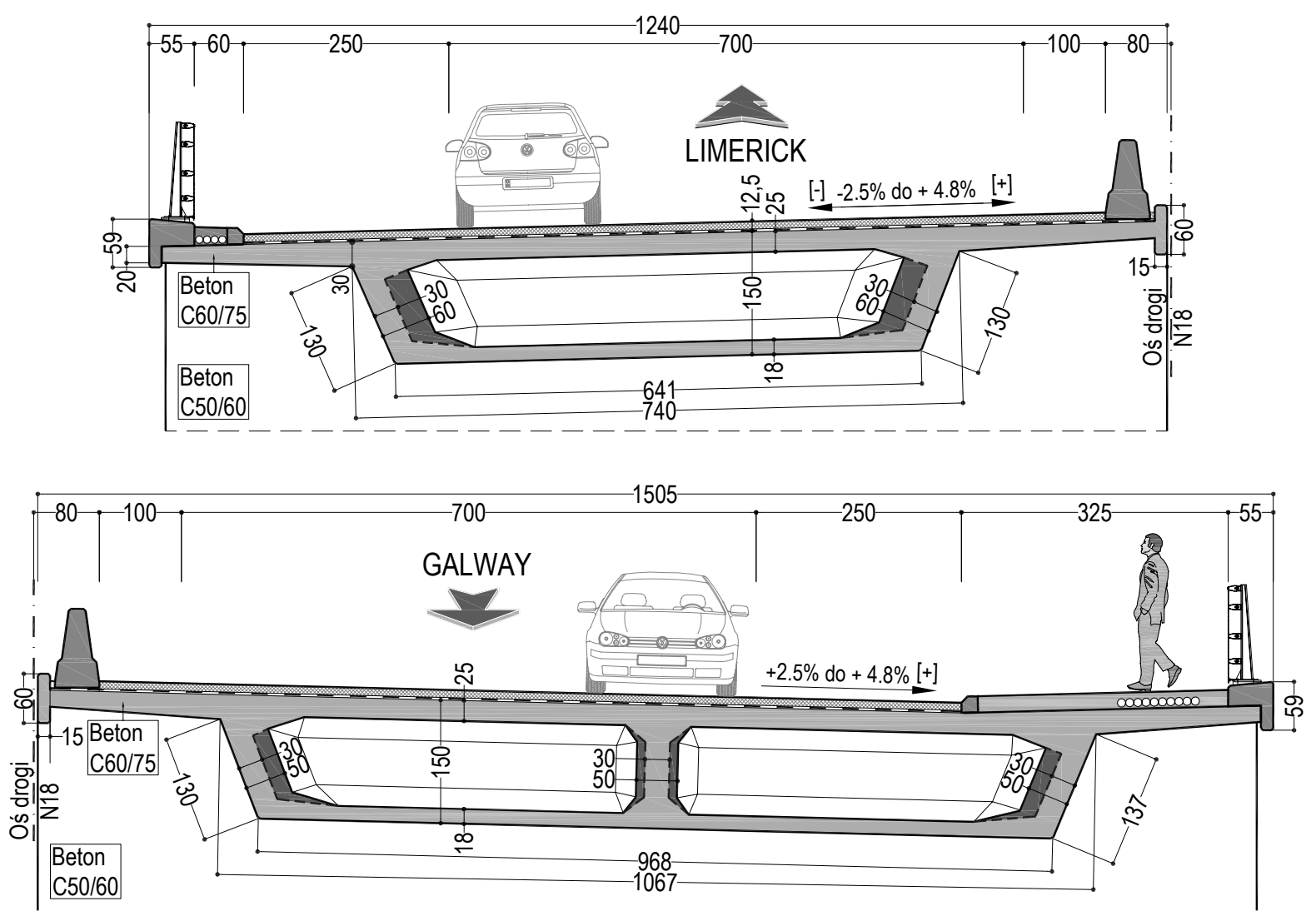

Rys. 6. Przekroje poprzeczne przęseł wiaduktów

Fig. 6. The cross-sections of the viaducts spans 
We wszystkich przęsłach o rozpiętości powyżej $30 \mathrm{~m}$ wykonano dwie żelbetowe przepony przęsłowe i dwie przepony podporowe w przekroju poprzecznym. Przepony podporowe są wspólne dla sąsiadujących przęseł (rys. 7). Przęsło o rozpiętości $14 \mathrm{~m}$ nie posiada przepony, natomiast przęsło o rozpiętości $26,5 \mathrm{~m}$ ma jedną przeponę przęsłową w odległości $10 \mathrm{~m}$ od osi skrajnego filara. Pozostałe przepony przęsłowe w obydwu wiaduktach znajdują się w odległości $10 \mathrm{~m}$ od osi podpór. Grubość tych elementów wynosi $35 \mathrm{~cm}$. W miejscu przepony przęsłowej łączone były fragmenty przęsła wykonane w pierwszym etapie jako wsporniki z częścią środkową przęsła wykonaną w kolejnym etapie. Część wspornikową przęsła wykonywano na pełnym rusztowaniu, natomiast część środkową przęsła - na platformach stalowych zawieszonych i zakotwiczonych w przeponach przęsłowych na końcach wsporników przęseł. W trakcie wykonywania przęseł komory wewnętrzne tych przęseł wypełniono w całej objętości blokami ze styropianu.

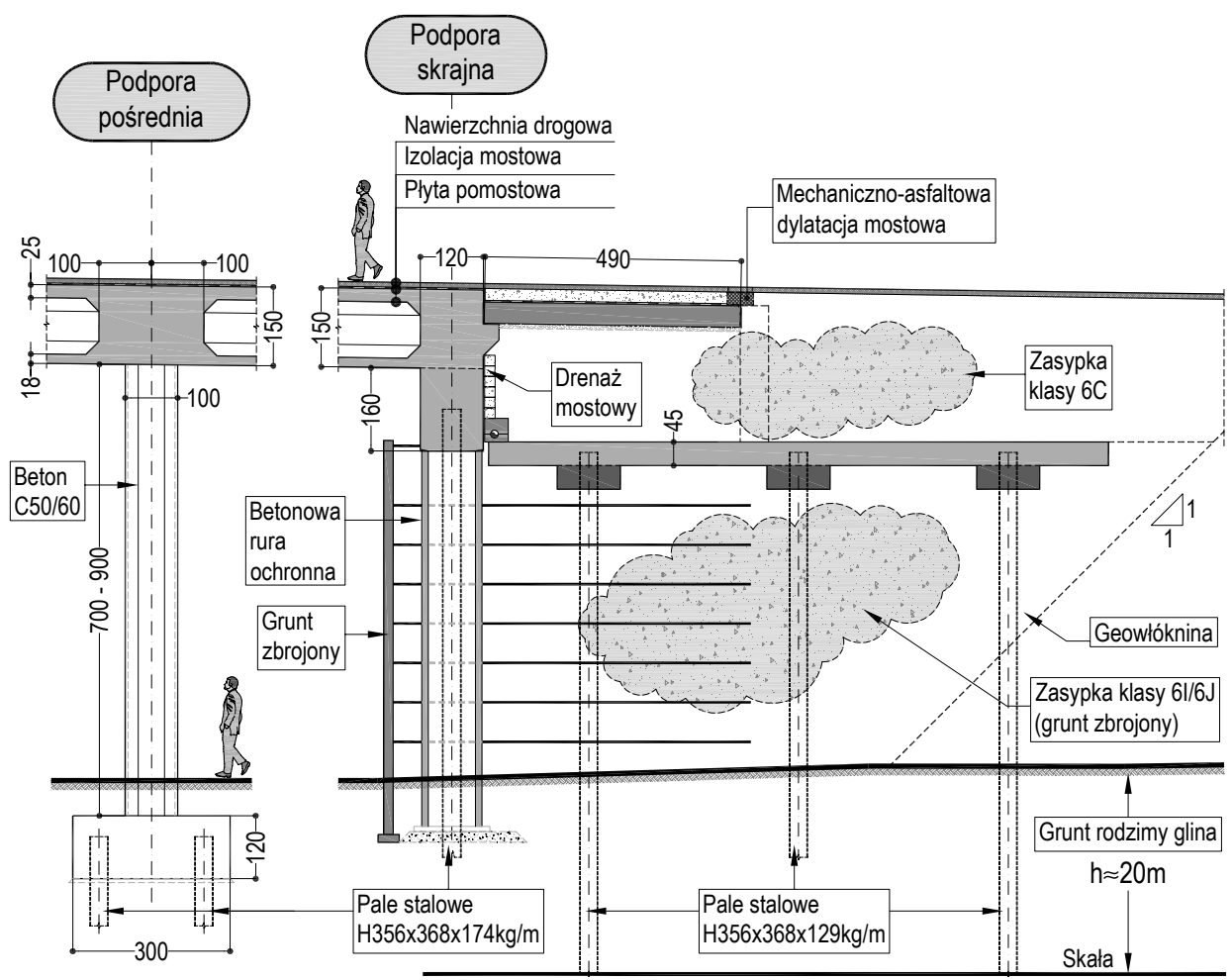

Rys. 7. Przekrój podłużny przez strefę podporową wiaduktów

Fig. 7. The cross-section of the viaducts supports

Dźwigary obydwu wiaduktów w części wspornikowej przęsła mają większą grubość. W wiadukcie północnym grubość dźwigarów wynosi $60 \mathrm{~cm}$, natomiast w wiadukcie południowym $-50 \mathrm{~cm}$. W części centralnej, o różnej długości, grubość dźwigarów wynosi $30 \mathrm{~cm}$ w obydwu konstrukcjach. Część wspornikowa i środkowa przęsła wykonywana była $\mathrm{w}$ trzech etapach. W etapie pierwszym wykonywano płytę dolną przęsła, w etapie drugim - dźwigary do wysokości spodu płyty górnej i w ostatnim etapie - płytę górną przęsła. Ze względu na wysoką klasę betonu C60/75 użytego do wykonania przęseł pojawiły się na ich powierzchni widoczne rysy skurczowe i termiczne. Rysy te zostały zabezpieczone w trakcie budowy. Należy dodać, że elementy żelbetowe w tych wiaduktach projektowane były na możliwość pojawienia się rys o rozwarciu nie większym niż 0,25 mm. Przęsła tych wiaduktów nie opierają się na łożyskach mostowych, lecz są monolitycznie połączone z podporami. 
Przemieszczenia poziome przęsła, związane w szczególności ze zmianami termicznymi powietrza w ciągu roku i hamowaniem pojazdów, przejmowane są przez wiotkie pale stalowe i przez elastyczne podpory.

\section{POŁĄCZENIE WIADUKTU Z NASYPEM}

Pod wpływem zmiany temperatury powietrza w ciągu roku obydwa wiadukty zmieniają swoją długość. Wydłużenie lub skrócenie przęsła wiaduktu w kierunku osi drogi powoduje m.in. to, że zasypka za ścianą przyczółka jest dogęszczana latem lub rozluźniana w okresie zimy. Rozluźnienie zasypki za przyczółkiem jest spowodowane odsuwaniem się ściany przyczółka od nasypu, osiadaniem nasypu i możliwym przedostawaniem się tam wody opadowej. Dodatkowo w strefie tej mamy do czynienia ze zmianą sztywności między tymi dwoma elementami. Najczęściej to nasyp jest bardziej elastyczny od sztywnej ściany przyczółka i w konsekwencji to nasyp ulega większemu osiadaniu niż przyczółek. W wyniku powyższych czynników w strefie tej w nawierzchni drogowej może tworzyć się latem garb, a zimą próg najazdowy. Wypukły garb lub wklęsły próg najazdowy powoduje, że pojazdy są wybijane przed najazdem na obiekt lub przy zjeździe z niego, przyczyniając się w ten sposób do przyśpieszonego niszczenie zarówno nawierzchni drogowej, nasypu drogowego, przyczółka mostowego, jak i poruszających się po drodze pojazdów.

Ze względu na znaczne długości obydwu wiaduktów podlegają one dużemu wydłużeniu w okresie lata lub skróceniu zimą. W związku z tym zastosowano w nich dylatacje mostowe i płyty przejściowe. W najdłuższym wiadukcie południowym, o długości całkowitej $179,7 \mathrm{~m}$, termiczne skrócenie lub wydłużenie wiaduktu może wynieść co najmniej $5 \mathrm{~cm}$. W obliczeniach tych założono, że zasypka za przyczółkiem została wbudowana w czerwcu danego roku. Zgodnie z normą BD37/01 (2001) minimalna temperatura powietrza w okolicy wiaduktu może wynieść $T_{\min }=-15^{\circ} \mathrm{C}$, natomiast maksymalna temperatura powietrza może osiągnąć wartość $T_{\max }=40^{\circ} \mathrm{C}$. W związku z tym krawędź zewnętrzna przyczółka po stronie nasypu przemieszcza się od i w kierunku nasypu o co najmniej $2,5 \mathrm{~cm}$ od położenia początkowego przyczółka. Stąd zastosowane dylatacje mostowe na obydwu końcach wiaduktu muszą przyjąć 2,5-centymetrowe wydłużenie lub 2,5-centymetrowe przesunięcie krawędzi ściany przyczółka od jego położenia początkowego. W jednym i drugim wiadukcie zastosowano dylatacje drogowe wbudowane $\mathrm{w}$ nawierzchnię drogową w miejscu połączenia płyty przejściowej i nasypu drogowego (rys. 7). Na obydwu obiektach odsunięcie dylatacji mostowej wzdłuż osi drogi na koniec płyty przejściowej zapobiega bezpośredniemu przedostawaniu się wody opadowej z nawierzchni drogowej między ścianę przyczółka i nasyp drogowy. W innym przypadku woda opadowa mogłaby przedostawać się między ścianę przyczółka i nasyp drogowy, co w konsekwencji powodowałoby wypłukiwanie drobnych frakcji kruszywa z podbudowy drogi i przyśpieszenie procesu tworzenia się progu najazdowego na wiadukt.

Dodatkowo ze względu na położenie wiaduktów na gruntach słabonośnych od strony północno-zachodniej w warstwie podbudowy drogi zastosowano żelbetową płytę przejściową natomiast od strony południowowschodniej konieczne było zastosowanie żelbetowej płyty dojazdowej zbudowanej na stalowych palach typu $\mathrm{H} 356 \times 368 \times 129 \mathrm{~kg} \cdot \mathrm{m}^{-1}$ (rys. 7) i nad nią w warstwie podbudowy drogi płyty przejściowej.

Należy stwierdzić, że po paru latach od wykonania tych wiaduktów nie zauważono zacieków wody opadowej na ścianach wiaduktów i wypukłego garbu lub wklęsłego progu najazdowego przed obydwoma wiaduktami. Przejeżdżając samochodem osobowym przez obydwie konstrukcje, nie odczuwa się wybicia przy najeżdżaniu i wyjeżdżaniu z wiaduktów.

\section{WNIOSKI}

Obydwa wiadukty oddano do użytku w drugiej połowie 2010 roku. W 2014 roku wykonano ich przegląd techniczny oraz innych obiektów na tym odcinku drogi, dla których wcześniej wykonano projekt sprawdzający. Przegląd ten polegał na dokładnym obejrzeniu całej konstrukcji. W trakcie przeglądu nie wykonano żadnych po- 
miarów, by dokładnie stwierdzić, co dzieje się z tymi wiaduktami. W obydwu obiektach nie zauważono nierównego osiadania ich podpór i nierównego osiadania ścian oporowych. Nie zauważono również zarysowań w ich konstrukcji, związanych z dużym wytężeniem. Widoczne były naprawy niektórych rys powstałych w przęsłach w trakcie ich budowy. Wobec powyższego należy mieć szczególną uwagę na wykonanie wszystkich elementów $\mathrm{z}$ betonu wysokich klas, gdyż niewłaściwe zabezpieczenie ich przed wpływem czynników zewnętrznych może prowadzić do powstawania w nich rys. Nie zauważono zacieków na zewnętrznych powierzchniach przęseł i ścianach przyczółków, jak również nie zaobserwowano w trakcie przejazdu po wiaduktach wypukłego garbu czy wklęsłego progu najazdowego. Na tej podstawie można stwierdzić, że przedstawione wiadukty zintegrowane dobrze współpracują z otaczającym je gruntem pod wpływem działania obciążeń stałych i zmiennych.

$\mathrm{Na}$ obiektach tych nie ma łożysk mostowych. Fakt ten czyni je tańszymi w budowie, w zestawieniu z tradycyjnie wykonywanymi wiaduktami, w których zastosowano łożyska mostowe. Prawie dziewięćdziesiąt lat temu do podobnych wniosków doszedł polski uczony profesor Wasiutyński (Wasiutyński 1985). Autor artykułu sugeruje, że należy budować jak najwięcej wiaduktów zintegrowanych w naszym kraju ze względu na to, że jest to szybsze i tańsze rozwiązanie konstrukcyjne wiaduktu. Należy mieć na uwadze, że w Polsce występuja inne wartości temperatury powietrza niż na Wyspach Brytyjskich, z tego też względu konieczne jest badanie tych konstrukcji w krajowych warunkach klimatycznych. Badania takie umożliwiłyby inżynierom mostowym wnikliwe poznanie pracy tych konstrukcji, co mogłoby prowadzić do stopniowego zwiększania ich długości. Na uwagę zasługuje fakt, że w Polsce pojawia się coraz więcej bardzo cennych publikacji na temat mostów i wiaduktów zintegrowanych (Furtak i Wrana, 2005; Machelski 2008, 2013; Jarosz i Radomski 2013). Świadczy to o rosnącym zainteresowaniu przez inżynierów mostowych w Polsce tymi konstrukcjami.

\section{PIŚMIENNICTWO}

BA42/96 (2003). The Design of Integral Bridges. Design Manual for Roads and Bridges, 1, 3, 12.

BD37/01 (2001). Loads for Highway Bridges. Design Manual for Roads and Bridges, 1, 3, 14.

BS5400-03 (2000). British Standard. Steel, concrete and composite bridges - Part 3: Code of practice for design of steel bridges.

BS5400-04 (1990). British Standard. Steel, concrete and composite bridges - Part 4: Code of practice for design of concrete bridges.

BS8002 (1994). British Standard. Code of practice for Earth retaining structures.

Furtak, K. i Wrana, B. (2005). Mosty zintegrowane. Warszawa: Wydawnictwo Komunikacji i Łączności.

Helowicz, A. (2015a). Wiadukty zintegrowane jednoprzęsłowe z prefabrykowanych dźwigarów sprężonych. Konferencja Naukowa, Bydgoszcz - Krynica Zdrój, 197- 205.

Helowicz A. (2015b). Mosty zintegrowane z prefabrykowanych dźwigarów sprężonych - doświadczenie projektanta. Inżynieria i Budownictwo, 12, 648-652.

Helowicz A. (2016). Mostowe obiekty systemu Matière - doświadczenie projektanta. Konferencja Naukowa, Bydgoszcz - Krynica Zdrój, 648-652.

Jarosz, J. i Radomski, W. (2013). Analiza numeryczna przemieszczeń mostowych konstrukcji zintegrowanych. Inżynieria i Budownictwo, 69 (6), 315-320.

Machelski, Cz. (2008). Modelowanie mostowych konstrukcji gruntowo-powłokowych. Wrocław: Dolnośląskie Wydawnictwo Edukacyjne.

Machelski, Cz. (2013). Budowa konstrukcji gruntowo-powłokowych. Wrocław: Dolnośląskie Wydawnictwo Edukacyjne.

Microsoft Bing Maps. Pobrano z lokalizacji http://www.bing.com.

National Road Authority. Urząd administracji rządowej w Irlandii, zarządzający drogami w tym kraju. Pobrano z lokalizacji: http://www.nra.ie.

NRA Manual (2000). Manual of Contract Documents for Road Works, 1. Specification for Road Works. National Road Authority.

Wasiutyński, Z. (1985). Pisma. Tom IV. Mosty i konstrukcje budowlane. Warszawa: Państwowe Wydawnictwo Naukowe. 


\section{MULTI-SPAN INTEGRAL VIADUCTS WITH BOX GIRDERS - THE DESIGNER EXPERIENCE}

\section{SUMMARY}

The paper describes integral bridges and presents examples of two multi-span integral viaducts, built using reinforced concrete elements. All the structures have been constructed along N18 national road from Limerick to Galway in Ireland. At the beginning, the design principles and modeling of an integral bridge have been described. Presented viaducts have been designed checked by the author of this paper. Some advantages and disadvantages of those structures have been discussed. The author is focused in particular on an integral viaducts design, its construction process, construction cost, and behavior during its service. The article concludes with a summary of author skills and knowledge about the design of integral multi-span viaducts, with recommendations as to the design of those bridges in Poland.

Key words: multi-span integral bridge, box girder, design and construction 